\title{
Sarcophagidae and Calliphoridae related to Rhinella schneideri (Anura, Bufonidae), Bothrops moojeni (Reptilia, Serpentes) and Mabuya frenata (Reptilia, Lacertilia) carcasses in Brasília, Brazil
}

\author{
Roger Maia Dias Ledo ${ }^{1}$, Rodrigo Meneses de Barros ${ }^{2,3}$ \& José Roberto Pujol-Luz ${ }^{1}$
}

\author{
${ }^{1}$ Departamento de Zoologia, Instituto de Ciências Biológicas, Universidade de Brasília, UnB, Campus Universitário Darcy Ribeiro, 70910-900 \\ Brasília-DF Brazil.rogerledo@unb.br; jrpujol@unb.br. \\ ${ }^{2}$ Instituto de Identificação, Polícia Civil do Distrito Federal, [CEP] Brasília-DF, Brazil; \\ ${ }^{3}$ Laboratório de Histologia, Morfologia, Faculdade de Medicina, Universidade de Brasília, UnB, Campus Universitário Darcy Ribeiro, 70910-900 \\ Brasília-DF, Brazil. rodrigo_mdebarros@yahoo.com.br
}

\begin{abstract}
Sarcophagidae and Calliphoridae related to Rhinella schneideri (Anura, Bufonidae), Bothrops moojeni (Reptilia, Serpentes) and Mabuya frenata (Reptilia, Lacertilia) carcasses in Brasília, Brazil. This paper presents a list of necrophagous insects associated with small size carrions of two reptiles and one amphibian, found in areas of riparian forests and Cerrado sensu stricto physiognomies in a Conservation Unit located in Brasilia, Distrito Federal. We found seven species of insects related to these carcasses, being five Sarcophagidae, one Calliphoridae and one Braconidae parasitoid wasp. Lucilia eximia and Peckia (Pattonella) intermutans were the most abundant species in the study, corroborating with other studies that suggests that these species have specializations for colonization of small size animal carcasses.
\end{abstract}

KEYWORDS. Forensic entomology; fly colonization, herpetology, necrophagous insects; small size carcasses.

RESUMO. Sarcophagidae e Calliphoridae associados às carcaças de Rhinella schneideri (Anura, Bufonidae), Bothrops moojeni (Reptilia, Serpentes) e Mabuya frenata (Reptilia, Lacertilia) em Brasília, Distrito Federal, Brasil. Este trabalho apresenta uma lista de insetos decompositores associados a carcaças de pequeno porte de dois répteis e de um anfíbio, encontrados em áreas de matas de galeria e de cerrado sensu stricto em unidades de conservação do Distrito Federal. Foram encontradas sete espécies de insetos associados a essas carcaças, sendo cinco sarcofagídeos, um califorídeo e uma vespa parasitóide Braconidae. Lucilia eximia e Peckia (Pattonella) intermutans foram as espécies mais abundantes, corroborando com outros estudos que sugerem que estas espécies apresentam especializações para a colonização de carcaças menores.

PALAVRAS-CHAVE. Carcaças de pequeno porte; colonização por moscas; entomologia forense; herpetologia; insetos decompositores.

Flies are the main organisms responsible for carcass disintegration during the carrion decay process (Payne 1965; Jirón \& Cartín 1981). Sarcophagidae and Calliphoridae are known to present immature stages that feed on vertebrate carcasses, being among the most responsible for corpse breakdown (Campobasso et al. 2001).

Knowledge about the biology of Sarcophagidae and Calliphoridae in natural habitats are fairly incipient, being the vast majority of these studies directed to forensic purposes (Campobasso et al. 2001; Carvalho et al. 2000). Most of the studies with necrophagous insects were conducted with mammal corpses (Johnson 1975; Jirón \& Cartín 1981), especially pigs (Reed 1958; Payne 1965; Carvalho \& Linhares 2001; Carvalho et al. 2004; Barros et al. 2008; Biavati et al. 2010), in order to extrapolate information from the decomposition process of these animals to human (Catts \& Goff 1992; Schoenly et al. 2006). Therefore, it is noticed that there are not many decomposition studies with other taxa of terres- trial vertebrates, especially amphibians and reptiles (Cornaby 1974; Kneidel 1984; Moretti et al. 2009). Similarly, it is also perceived that most studies of necrophagous insects were performed with large size animals, do not existing many decomposition studies directed to study insects related to small size animals (Moretti et al. 2008; Moretti et al. 2009).

Amphibians and reptiles are very abundant in communities and are considered as model-organisms for several types of studies (Huey et al. 1983; Shine \& Bonnet 2000; Vitt \& Pianka 2005). Moreover, most of these animals are of small size. Thus, studying necrophagous insects associated with this type of ephemeral resource can provide a lot of information about colonization and establishment of Sarcophagidae and Calliphoridae in small animal carcasses. Therefore, this present work aims to report the fauna of necrophagous insects emerged from two reptilian and one amphibian carcasses, occasionally found in conserved units in the Brazilian Cerrado. 
During the years of 2007 and 2008, three carcasses (two reptiles and one amphibian) were occasionally found in decomposition process in the APA Gama-Cabeça-de-Veado protection area during long-term field works with herpetological studies. The APA Gama-Cabeça-de-Veado is a area located in the Distrito Federal, in the center of the Brazilian Cerrado, and is composed by several other conservation units; among them, the Reserva Ecológica do IBGE and the Estação Ecológica do Jardim Botânico de Brasília (EEJBB) (Fig. 1).

In January 2007, a juvenile frog Rhinella schneideri (Werner, 1894) (aprox. $55 \mathrm{~mm}$ ) was found dead at the edge of a riparian forest in the EEJBB. In February 2007 and adult snake Bothrops moojeni Hoge, 1966 (aprox. 100cm) was found in the interior of a riparian forest at the Monjolo stream, in the Reserva Ecológica do IBGE. In the same conservation unit, an adult lizard species Mabuya frenata (Cope, 1862) (snout-vent length $=60 \mathrm{~mm}$ ) was found in a cerrado sensu stricto physiognomy under controlled experimental fire regimes (Miranda et al. 2011), in September 2008. All carcasses were found with signs of advanced decomposition (bloating and putrid odor) and had insect larvae activity.

The carcasses were collected on the same day they were found and were taken to the laboratory of forensic entomology at the Universidade de Brasilia, where each one was placed inside plastic recipients containing vermiculite for insect pupation. Due to the size of the Bothrops moojeni carcass, this specimen was sectioned in three parts and each one was stored separately. All recipients were covered with escaline textile fabric and bound with rubber bands and transferred to B.O.D. chamber adjusted to temperature of $25^{\circ} \mathrm{C}$, relative humidity of $60 \%$ and photophase of 12 hours.

After emergence, the insects were quantified and identified with the support of the taxonomic keys of McAlpine et al. (1981), Mello (2003) and de Carvalho \& Mello-Patiu (2008). All material was deposited in the Coleção Entomológica do Departamento de Zoologia, in the Universidade de Brasília.

Only one species of Sarcophagidae emerged from the carcasses of Rhinella schneideri and Mabuya frenata. From the carcass of the snake Bothrops moojeni, three Sarcophagidae species, one Calliphoridae and one Braconidae parasitoid wasp emerged (Table I).

Sarcodexia lambens (Wiedemann, 1830), Peckia (Pattonella) intermutans (Walker, 1861) and Peckia (Squamatodes) trivittata (Curran, 1927), found in the studied carcasses, were also found in carcasses of pigs in the Cerrado (Barros et al. 2008; Rosa et al. 2009), but always in lower abundance levels than other necrophagous flies of the community. Moretti et al. (2008) found that $P$. (P.) intermutans occurred in all experiments with small size rodent carcasses, suggesting that this species has a specialization to the colonization of animal carcasses with small sizes.

Peckia (Squamatodes) trivittata is known to only occur in campo cerrado regions (Lopes 1973), and in this study

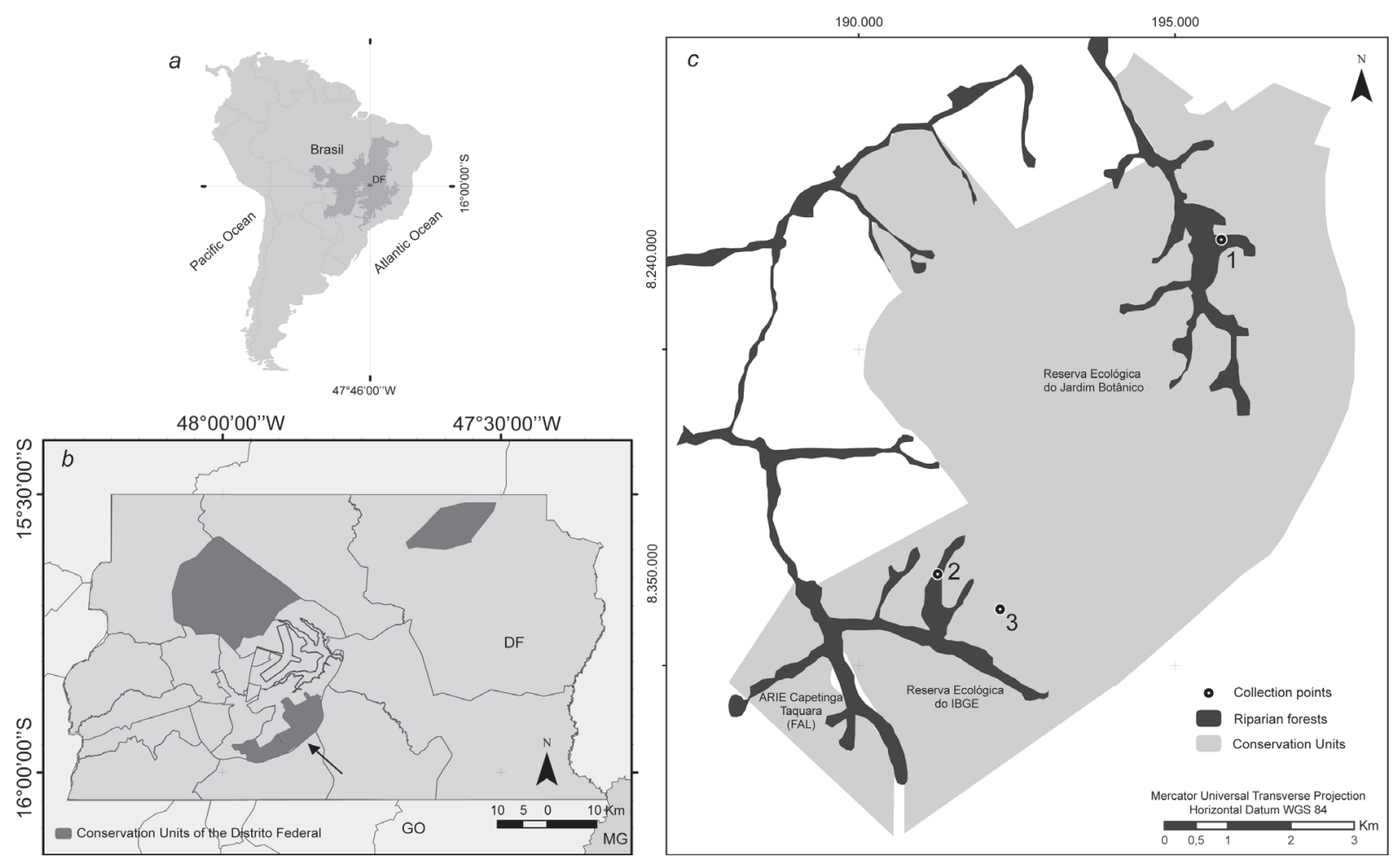

Fig. 1. Places where we found the carcasses of this study. (a) South America indicating the Cerrado domain and the Distrito Federal-DF, in central Brazil. (b) The Distrito Federal indicating the APA Gama-Cabeça-de-Veado (arrow). (c) Part of the APA Gama-Cabeça-de-Veado indicating the Reserva Ecológica do Jardim Botânico de Brasília and the Reserva Ecológica do IBGE, with the localities where we found the three carcasses: 1. Rhinella schneideri; 2. Bothrops moojeni; 3. Mabuya frenata. 
Table I. Frequency of insects associated to Rhinella schneideri (Anura, Bufonidae), Bothrops moojeni (Reptilia, Serpentes) and Mabuya frenata (Reptilia, Lacertilia) carcasses in conservation units of the APA Gama-Cabeça-de-Veado, in Brasilia, Brazil. The numbers below represent emerged insect abundance for each species.

\begin{tabular}{|c|c|c|c|}
\hline Species composition & Toad (Rhinella schneideri) & Lizard (Mabuya frenata) & Snake (Bothrops moojeni) \\
\hline \multicolumn{4}{|l|}{ Diptera } \\
\hline \multicolumn{4}{|l|}{ Sarcophagidae } \\
\hline Sarcodexia lambens (Wiedemann, 1830) & 4 & - & - \\
\hline Oxysarcodexia sp. & - & - & 1 \\
\hline Dexosarcophaga sp. & - & - & 4 \\
\hline Peckia (Squamatodes) trivittata (Curran, 1927) & - & 5 & - \\
\hline Peckia (Pattonella) intermutans (Walker, 1861) & - & - & 17 \\
\hline \multicolumn{4}{|l|}{ Calliphoridae } \\
\hline Lucilia eximia (Wiedemann, 1919) & - & - & 31 \\
\hline \multicolumn{4}{|l|}{ Hymenoptera } \\
\hline \multicolumn{4}{|l|}{ Braconidae } \\
\hline Braconidae sp. & - & - & 7 \\
\hline
\end{tabular}

this species was registered in another Cerrado physiognomy, a cerrado sensu stricto. However, this result does not contradict the previous studies of this species occurrence, since the area we recorded this insect is a cerrado sensu stricto disturbed by a recurring fire regime, which may influence the vegetation structure of this physiognomy (Miranda et al. 2011).

Lucilia eximia (Wiedemann, 1919) was the most abundant species in the Bothrops moojeni snake carcass. This species is widely distributed in the Americas, from the southern United States to Paraguay and Argentina and has been found causing myiasis (Lopes \& Leite 1989) in other vertebrates carrions, such as pigs (Biavati et al. 2010), and the same presents forensic importance, because it occurs in carcasses since the beginning stages of decomposition (Moura et al. 1997; Carvalho et al. 2000). Moretti et al. (2008) reported that $L$. eximia was the most abundant species in studies of colonization in small size carcasses of rodents, and with $P$. $(P$. intermutans, occurred in all experiments with this kind of carrion, suggesting that this species has a high specialization in the colonization of small size carcass resources.

The present work similarly found some individuals of Sarcophagidae (genus Dexosarcophaga) emerged from the carcass of the snake Bothrops moojeni that could not be identified. Moretti et al. (2009) pointed out that there are very few studies of vertebrate small size carcasses decomposition, especially of non-mammals, and, therefore, it is perfectly plausible to find new insect species associated with such ephemeral resource. Furthermore, the Brazilian Cerrado is highly diverse, poorly studied and under intense anthropogenic activity (Myers et al. 2000; Mittermeier et al. 2005), with estimates that more than a half of this area has been devastated (Klink \& Machado 2005).

Studies, such as Denno \& Cothran (1976), pointed out that Sarcophagidae and Calliphoridae have different strategies in use of carcass resources. In Sarcophagidae, most species are viviparous, eliminating first-instar larvae directly into the posture, which immediately begin their feeding on the corpse. Calliphorids, in turn, are oviparous and require an additional time for egg hatching (Denno \& Cothran 1976; Shewell 1987). Based on this, Barros et al. (2008) hypothesized that Sarcophagidae presents pioneerism in corpse colonization in relation to Calliphoridae. Based on this hypothesis, we could expect that the pioneerism of Sarcophagidae in relation to Calliphoridae could be reflected clearly in small size corpses, since this type of carrion contains little resources and that directly placed larvae in this substrate (which is the case of Sarcophagidae) would use the resource in shorter time, not enough time for the development of Calliphoridae larvae. According this work, this hypothesis was supported. Carcasses of the lizard and the frog had only registers of Sarcophagidae species. In the same way, from the snake carrion emerged five species and three were sarcophagids. Lucilia eximia was the only calliphorid registered in this study, emerged from the snake carrion. However, studies testing this hypothesis need to be performed. Apparently, the colonization of necrophagous insects on small size carrions is different from large size carrions (Blackith \& Blackith 1988; Moretti et al. 2009; Moretti 2006). Except for Lucilia eximia, it is probable that Sarcophagidae is the main family of necrophagous insects related to small size carrion reduction in the Cerrado, because of the life history traits of this family. Supporting this point of view, there are several records of Sarcophagidae in small size Invertebrates, such as cockroaches (Periplaneta americana), lepidopteran larvae and gastropods (Lopes 1973). In the same way, there are no records of blowflies (Calliphoridae) colonizing invertebrate carcasses of small size (Moretti 2006).

\section{ACKNOWLEDGEMENTS}

We thank G.R. Colli, coordinator of the long-term project entitled Ecology of Lizards in Riparian Forests of the Cerrado, for allowing study with the carcasses used in this work. This study received financial supports of $\mathrm{CNPq}, \mathrm{CAPES}$, and FINATEC. 


\section{REFERENCES}

Barros, R. M. de; C. A. de Mello-Patiu \& J. R. Pujol-Luz. 2008. Sarcophagidae (Insecta, Diptera) associados à decomposição de carcaças de Sus scrofa Linnaeus (Suidae) em área de Cerrado do Distrito Federal, Brasil. Revista Brasileira de Entomologia 52: 606-609.

Biavati, G. M.; F. H. de A. Santana \& J. R. Pujol-Luz. 2010. A checklist of Calliphoridae blowflies (Insecta, Diptera) associated with a pig carrion in Central Brazil. Journal of Forensic Sciences 55: 1603-1606.

Blackith, R. \& R. Blackith. 1988. Sarcophagini from northern Sulawesi (Indonesia), including four new species (Diptera, Sarcophagidae). Japanese Journal of Sanitary Zoology 39: 301-311.

Campobasso, C. P.; G. Di Vella \& F. Introna. 2001. Factors affecting decomposition and Diptera colonization. Forensic Science International 120: $18-27$.

Carvalho, L. M. L de \& A. X. Linhares. 2001. Seasonality of insect succession and pig carcass decomposition in a natural forest area in southeastern Brazil. Journal of Forensic Sciences 46: 604-608.

Carvalho, L. M. L.; P. J. Thyssen; A. X. Linhares \& F. A. B. Palhares. 2000. A checklist of arthropods associated with pig carrion and human corpses in Southeastern Brazil. Memórias do Instituto Oswaldo Cruz 95: 135138.

Carvalho, L. M. L.; P. J. Thyssen; M. L. Goff \& A. X. Linhares. 2004. Observations on the succession patterns of necrophagous insects on a pig carcass in an urban area of southeastern Brazil. Anil Aggrawal's Internet Journal of Forensic Medicine and Toxicology 5: 33-39.

Catts, E. P. \& M. L. Goff. 1992. Forensic entomology in criminal investigations. Annual Review of Entomology 37: 253-272.

Cornaby, B. W. 1974. Carrion reduction by animals in contrasting tropical habitats. Biotropica 6: 51-63.

de Carvalho, C. J. B. \& C. A. de Mello-Patiu. 2008. Key to the adults of the most common forensic species of Diptera in South America. Revista Brasileira de Entomologia 52: 390-406.

Denno, R. F. \& W. R. Cothran. 1976. Competitive interactions and ecological strategies of Sarcophagid and Calliphorid flies inhabiting rabbit carrion. Annals of the Entomological Society of America 69: 109-113.

Huey, R. B.; E. R. Pianka \& T. W. Schoener. 1983. Lizard ecology: studies of a model organism. Cambridge, Harvard University Press, $501 \mathrm{p}$.

Jirón, L. F. \& V. M. Cartín. 1981. Insect succession in the decomposition of a mammal in Costa Rica. Journal of the New York Entomological Society 89: $158-165$.

Johnson, M. D. 1975. Seasonal and microseral variations in the insect populations on carrion. American Midland Naturalist 93: 79-90.

Klink, C. A. \& R. B. Machado. 2005. Conservation of the Brazilian Cerrado. Conservation Biology 19: 707-713.

Kneidel, K. A. 1984. Influence of carcass taxon and size on species composition of carrion-breeding Diptera. American Midland Naturalist 111: 57-63.

Lopes, H. de S. 1973. Collecting and rearing Sarcophagid flies (Diptera) in Brazil, during forty years. Anais da Academia Brasileira de Ciências 45: 279-299.

Lopes, H. de S.; Leite, A. C. R. 1989. Morphology of the egg of Sarcodexia lambens (Diptera: Sarcophagidae). Memórias do Instituto Oswaldo Cruz 84: 97-50.
McAlpine, J. F.; B. V. Peterson; G. E. Shewell; H. J. Teskey; J. R. Vocherot \& D. M. Wood. 1981. Manual of Neartic Diptera. Ottawa, Agriculture Canada. I $+674 p$

Mello, R. P. 2003. Chave para identificação das formas adultas das espécies da família Calliphoridae (Diptera, Brachycera, Cyclorrapha) encontradas no Brasil. Entomogía y Vectores 10: 255-268.

Miranda, H. S.; M. N. Sato; S. M. de A. Andrade; B. M. de C. Neves; C. A. N. Quesada; L. A. Z. de Andrade; A. E. Ramos; M. B. de Medeiros; A. J. B. Santos; P. C. da Silva \& J. M. F. Maia. 2011. Projeto fogo, p. 162177. In: M. L. Ribeiro (ed). Reserva Ecológica do IBGE. Instituto Brasileiro de Geografia e Estatística - IBGE. (tomo 1)+300 p.

Mittermeier, R. A.; P. R. Gil; M. Hoffman; J. Pilgrim; T. Brooks; C. G. Mittermeier; J. Lamoreux \& G. A. B. da Fonseca. 2005. Hotspots revisited: Earth's biologically richest and most endangered terrestrial ecoregions. Conservation International, Washington, $392 \mathrm{p}$.

Moretti, T. de C. 2006. Artrópodes associados às carcaças de pequenos roedores expostas em área de formação vegetal secundária no município de Campinas, SP. Dissertação de Mestrado. Campinas, Universidade Estadual de Campinas.

Myers, N.; R. A Mittermeier; Mittermeier, C. G.; da Fonseca, G. A. B.; Kent, J. 2000. Biodiversity hotspots for conservation priorities. Nature 403: 853-858.

Moretti, T. de C.; S. M. Allegretti; C. A. Mello-Patiu; A. M. Tognolo; O. B. Ribeiro \& D. R. Solis. 2009. Occurrence of Microcerella halli (Engel)(Diptera, Sarcophagidae) in snake carrion in southeastern Brazil. Revista Brasileira de Entomologia 53: 318-320.

Moretti, T. de C.; O. B. Ribeiro; P. J. Thyssen \& D. R. Solis. 2008. Insects on decomposing carcasses of small rodents in a secondary forest in Southeastern Brazil. European Journal of Entomology 105: 691-696.

Moura, M. O.; C. J. B. de Carvalho \& E. L. A. Monteiro-Filho. 1997. A preliminary analysis of insects of medico-legal importance in Curitiba, State of Paraná. Memórias do Instituto Oswaldo Cruz 92: 269-274.

Payne, J. A. 1965. A summer carrion study of the baby pig Sus scrofa Linnaeus. Ecology 46: 592-602.

Reed Jr., H. B. 1958. A study of dog carcass communities in Tennessee, with special reference to the insects. American Midland Naturalist 59: 213-245.

Rosa, T. A.; M. L. Y. Babata; C. M. de Souza; D. de Sousa; C. A. de MelloPatiu \& J. Mendes. 2009. Dípteros de interesse forense em dois perfis de vegetação de cerrado em Uberlândia, MG. Neotropical Entomology 38: 859-866.

Schoenly, K. G.; N. H. Haskell; D. K. Mills; C. Bieme-Ndi; K. Larsen \& Y. Lee. 2006. Recreating death's acre in the school yard: using pig carcasses as model corpses to teach concepts of forensic entomology \& ecological succession. The American Biology Teacher 68: 402-410.

Shewell, G. 1987. Sarcophagidae. p. 1159-1186. In: J. P. McAlpine; B. V. Paterson; G. E. Shewell; H. J. Teskey; J. R. Vockeroth \& D. M. Wood (Eds.). Manual of Nearctic Diptera Research Branch, Agriculture Canada, Monograph 28. Volume II $+657 \mathrm{p}$.

Shine, R. \& X. Bonnet. 2000. Snakes: a new 'model organism' in ecological research? Trends in Ecology \& Evolution (Personal edition) 15: 221222.

Vitt, L. J. \& E. R. Pianka. 2005. Deep history impacts present-day ecology and biodiversity. Proceedings of the National Academy of Sciences of the United States of America 102: 7877-7881. 